\title{
Reproductive cycle of the steppe polecat (Mustela eversmanni)
}

\author{
R. A. Mead, S. Neirinckx and N. M. Czekala* \\ Department of Biological Sciences, University of Idaho, Moscow, Idaho 83843, USA; and \\ * Research Department, Zoological Society of San Diego, San Diego, California 92112, USA
}

\begin{abstract}
Summary. In laboratory conditions, in a natural photoperiod, testicular redevelopment began in late December. Maximal testis size was attained by the end of February. Testicular regression began in mid-May and was complete by the end of August. Oestrus was first observed in late March and continued throughout April. Females mated for the first time between 30 March and 8 April. Mating generally coincided with peak concentrations of urinary oestrone conjugates and when vaginal lavages contained $>90 \%$ cornified epithelial cells. Blastocyst implantation occurred by Day 13 and the post-implantation period was 29 days. Gestation ranged from 39 to 43 days and first parturition occurred in mid-May. Concentrations of urinary oestrone conjugates and free progesterone were elevated during the first half of pregnancy, reaching maximum values at mid-pregnancy, and then gradually declined as parturition neared. Litter size of primiparous females averaged 6.8 young/female. Females that were pseudopregnant or lost their litters shortly after birth, and several with weaned kits, exhibited a second oestrus.
\end{abstract}

Key'words: steppe polecat; oestrous cycle; testis; pregnancy; urinary steroids

\section{Introduction}

The steppe polecat (Mustela eversmanni) occupies the plains of the USSR, Romania, Hungary, Czechoslovakia, Yugoslavia, and eastern China. Wild populations of all 3 species of ferrets are in decline throughout much of their range and the black-footed ferret (Mustela nigripes), to which the steppe polecat is most closely related (O'Brien et al., 1989), is near extinction. Captive breeding may represent the only hope of maintaining genetic stocks of some species or populations. However, a detailed study of reproduction in the steppe polecat has, to the best of our knowledge, never been undertaken although a few anecdotal descriptions have been published (Schmidt, 1932; Novikov, 1956; Stroganov, 1962; Carpenter \& Hillman, 1978; Zheng et al., 1983). Therefore a more comprehensive understanding of its reproductive biology would appear warranted and should provide a more accurate assessment of the similarities and differences in the reproductive biology of ferrets. The objectives of this study were to define the breeding season, oestrous and testicular cycles, and duration of pregnancy in the steppe polecat. An additional objective was to examine a non-invasive method for monitoring the oestrous cycle by measuring urinary steroids.

\section{Materials and Methods}

Animals. Twenty subadult steppe polecats (Mustela eversmanni), from 3 litters born to polecats obtained from Russia, were received from Wyoming Game and Fish Department on 3 August 1987, when the animals were 3 months old. Six females and 4 males were placed in a windowless animal room in which the photoperiod was controlled by a Tork Model $7122 Z$ light timer (Tork Inc., Mt Vernon, NY, USA) that was set to simulate precisely the natural photoperiod at our latitude of $46^{\circ} 43^{\prime} 57^{\prime \prime} \mathrm{N}$. An additional 6 females and 4 males were exposed to short-day $8 \mathrm{~h}$ light: $16 \mathrm{~h}$ dark 
(8L:16D) photoperiods for 2 months followed by long-day (16L:8D) photoperiods for 4.5 months in an attempt to induce precocious puberty and 2 reproductive cycles within a single year. Aspects of that study will be the topic of another paper. Data from the latter group have only been used to provide additional information as to the duration of pro-oestrus, oestrus, gestation, and development of the kits. No data regarding reproduction in males from the latter group have been included. All animals were individually housed and were provided with Purina Ferret Chow and water ad libitum. Plastic wash pans filled with Aspinite (American Excelsior Company, Chelmsford, MA, USA) served as nest boxes.

Vaginal lavages were obtained once each week throughout most of the year but were taken every other day or daily before and during oestrus. Approximately 100 cells from each saline lavage were classified with the aid of a compound microscope as being cornified or non-cornified. The degree of vaginal cornification has been expressed as the mean \pm s.d. percentage of cornified cells in the vaginal smear. The length and width of the vulva were measured with a millimetre ruler. When vaginal cornification exceeded $90 \%$, the female was placed with a distantly related (i.e. non-litter mate) male. If the male showed interest, they were left together and checked at 20-30-min intervals to determine whether intromission had occurred. A vaginal lavage was taken at the end of each copulatory bout to check for the presence of spermatozoa. Each female was mated again on the same or subsequent day. The first day that spermatozoa were found in the vaginal lavage was considered to be Day 0 of pregnancy, as ovulation in the domestic ferret (Mustela putorius furo) is induced by coitus and occurs approximately $30-36 \mathrm{~h}$ after copulation (Robinson, 1918; Hammond \& Walton, 1934).

The males were anaesthetized with ketamine $(40 \mathrm{mg} / \mathrm{kg}$, i.m.; Vetalar, Parke-Davis, Morris Plains, NJ, USA) once every other week. The right testis of each animal (length and width) was measured through the scrotum with calipers. Electroejaculation was performed on lightly sedated animals at infrequent intervals, using a bipolar electrode $1 \mathrm{~cm}$ in diameter (Healey \& Sadleir, 1966) and a Nicholson stimulator, to determine whether males were capable of ejaculating motile spermatozoa.

Urine collection. Urine samples $(\sim 5 \mathrm{ml})$ were collected from 5 mature females, maintained in the long-day photoperiod, at about 4-day intervals before the start of the breeding season and at nearly daily intervals during oestrus, pregnancy $(\mathrm{N}=4)$ and pseudopregnancy $(\mathrm{N}=1)$. A small, clean aluminium pan, covered with Teflon mesh to exclude faecal material, was placed in the dropping pan of each cage in the evening and the urine removed the next morning. Samples were frozen until hormone analysis.

Hormone assays. In preliminary studies the composition of oestrogens in urine from oestrous females was characterized as predominantly in the conjugated form $(63 \%$ conjugated, $37 \%$ free). The conjugate fraction was applied to a high-pressure liquid chromatograph after hydrolysis (glucuronidase aryl sulphatase: Boehringer Mannheim, Indianapolis, IN, USA) and diethyl ether extraction to determine other forms of oestrogen present. Oestrone conjugates and oestradiol conjugates $(2 \cdot 7: 1)$ were the major metabolites present in such urine. Urine was analysed for oestrone conjugates by radioimmunoassay (RIA) as previously described (Shideler et al., 1983; Czekala et al., 1988). Oestrone conjugates in undiluted urine $(0.01 \mathrm{ml})$ were measured using antiserum which cross-reacts equally to free oestrone, oestrone glucuronide and oestrone sulphate (anti-oestrone glucuronide, 0.01 ml, 1:5000, D. C. Collins, Emory University, Atlanta, GA, USA) and using tritiated oestrone sulphate (0.01 ml, 7000 c.p.m., sp. act. $55 \mathrm{Ci} / \mathrm{mmol}$ : New England Nuclear, Boston, MA, USA). The standard curve for oestrone sulphate ranged from 30 to $5000 \mathrm{pg}$.

Serial dilutions of urine from oestrous polecats were assayed by RIA for oestrone conjugates and found to be parallel with the standard curve $(r=0.99)$. Oestrone sulphate (sodium salt) (150-1250 pg) added to urine from prooestrous females was recovered at $100-120 \%$. Inter-assay coefficient of variation was $10.6 \%$ and $8 \%$ at $93 \%$ and $57 \%$ binding, respectively. Intra-assay coefficient of variation was $4 \%$ and $1 \%$ at $22 \%$ and $65 \%$ binding, respectively. Sensitivity (zero minus 2 s.d.) was $39 \mathrm{pg}$.

Unconjugated progesterone was measured using a modified method of Abraham et al. (1971). Undiluted urine ( $1 \mathrm{ml}$ ) was extracted with $5 \mathrm{ml}$ diethyl ether, dried, and reconstituted in $1 \mathrm{ml}$ phosphate-buffered saline (pH 7.0). An aliquant $(0.5 \mathrm{ml})$ was combined with progesterone antiserum (antiprogesterone-11-hemisuccinate-BSA, $0.1 \mathrm{ml}$, 1:100 000: S.S.C. Yen, San Diego, CA, USA) and tritiated progesterone $(0 \cdot 1 \mathrm{ml}, 10000$ c.p.m., sp. act. $115 \mathrm{Ci} / \mathrm{mmol}$ : New England Nuclear, Boston, MA, USA). The standard curve for progesterone ranged from 7 to $2000 \mathrm{pg}$. Bound and free labelled hormone were separated by incubation with dextran-coated charcoal as previously described. Crossreactivity of the antiserum was: progesterone $100 \% ; 5 \beta$-pregnane-3,20-dione $13 \%$; $5 \alpha$-pregnane-3,20-dione $5 \cdot 2 \%$; $17 \alpha$-hydroxyprogesterone $1.5 \%$; corticosterone $0.9 \% ; 20 \alpha$-hydroxypregn-4-ene-3-one $0.65 \%$; deoxycorticosterone $0.5 \%$; androstenedione $1 \cdot 3 \%$; other steroids tested $<0.1 \%$.

Progesterone values in serial dilutions of urine from animals at mid-gestation were parallel to the standard curve $(r=0.99)$. Tritiated progesterone was added to urine of females after copulation and purified by Celite chromatography (Abraham et al., 1971); the unlabelled and $\left[{ }^{3} \mathrm{H}\right]$ progesterone eluted as one peak and were quantified. Celitechromatographed and non-chromatographed urine yielded similar amounts of progesterone $(847$ and $999 \mathrm{pg} / \mathrm{ml}$ respectively); therefore the progesterone assay was performed without chromatography. Recovery of added progesterone to urine from a pro-oestrous female was $100-140 \%(r=0.99 \%)$. Inter-assay coefficient of variation was $13.6 \%$ and $7 \%$ at $45 \%$ and $25 \%$ binding, respectively. Intra-assay coefficient of variation was $7 \%$ and $8 \%$ at $17 \%$ and $43 \%$ binding, respectively. Sensitivity of the assay was $15 \mathrm{pg}$.

All concentrations of hormone are expressed as $\mathrm{ng}$ per $\mathrm{mg}$ creatinine $(\mathrm{Cr})$ to correct for variation in urine concentration (Taussky \& Kurzmann, 1954). Calculations of mean \pm s.e.m. values up to the day of copulation include all 5 females, while calculations after the day of copulation include only the 4 pregnant animals. 


\section{Results}

\section{Males}

The testes were scrotal throughout the year, but completely regressed testes were difficult to detect without anaesthetizing the animals. At that time the testes averaged $1.2 \times 0.7 \mathrm{~cm}$ (length $\times$ width). Testicular redevelopment was first detected on 21 December in males exposed to a natural photoperiod (Fig. 1). Testicular size steadily increased and reached maximal size $(2.3 \times 1.3 \mathrm{~cm}) 71$ days later on 29 February. Electroejaculation was attempted on 1 February. None of the 4 males produced a typical ejaculate at that time. However, a minute amount of fluid collected from the tip of the penis contained a few non-motile spermatozoa in 3 of the males. Only spermatids were present in fluid collected from the 4 th male. All 4 males successfully copulated with 1 or more oestrous females between $30 \mathrm{March}$ and $8 \mathrm{April}$, as indicated by the presence of motile spermatozoa in the vaginal lavage. Testicular size was maintained near maximum until 9 May, or for approximately 70 days, but then regression began to occur. One male successfully copulated on 18 May with a female that had returned to oestrus after the death of her litter. Moreover, 3 of 4 males electroejaculated on 6 June produced semen of excellent quality with respect to sperm morphology and forward motility but no attempt was made to quantify sperm numbers. Another male successfully copulated on 11 August with a female that had returned to oestrus after her previous litter had been weaned. Testicular regression was complete in 2 of the 4 males by 15 August. The testes of the other 2 males did not completely regress until 29 August and 24 October.

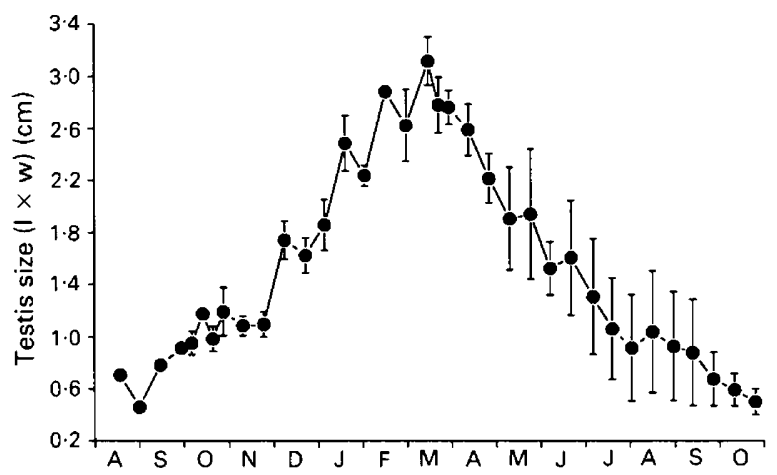

Fig. 1. Seasonal changes in testicular size (mean \pm s.e.m.) in 4 captive steppe polecats maintained in a natural photoperiod.

\section{Females}

All 6 females maintained in a natural photoperiod remained anoestrous until early March. During anoestrus the vulva was completely flush with the surrounding perivaginal region and vaginal cornification was generally less than $25 \%$ (Fig. 2 ). However, by 25 January, vaginal cornification began consistently to exceed $25 \%$ and continued an erratic but progressive increase throughout February and March. Slight vulval swelling $(1 \times 2 \mathrm{~mm}$, length $\times$ width $)$ was first detected in 2 females on $18 \mathrm{March}$, at which time their vaginal cornification had reached 67 and $73 \%$. Prooestrus, defined as the period from the first sign of vulval swelling to the first vaginal lavage containing $>90 \%$ cornified epithelial cells, averaged $7 \cdot 3 \pm 3.4$ days. Oestrus, defined as vaginal lavages containing $>90 \%$ cornified epithelial cells, was first observed in 1 of 6 females on 23 March. At this time, vulval swelling was quite apparent and had increased to $3 \times 6 \mathrm{~mm}$. The first 
successful matings (spermatozoa in the vaginal lavage) occurred on 30 March (3 of the 6 females bred). Copulation was only observed to occur in females in which vaginal cornification had reached $90 \%$. Most females did not permit copulation until vaginal cornification had reached $94 \%$ and the vulva averaged $8 \pm 4 \times 9 \pm 2 \mathrm{~mm}$ (length $\times$ width). Measurements of percentage of vaginal cornification and urinary oestrone conjugates were highly correlated and paralleled one another before mating (Fig. 3). Mating coincided with peak concentrations of oestrone conjugates in 3 animals, but occurred 1 day before the oestrone conjugate peak in 1 female, and 4 days before the oestrone conjugate peak in another. For the first 5 days after mating, urinary oestrone conjugate concentrations declined, then rose to levels greater than those observed at oestrus by 10 days after copulation, remained elevated until Day 25 and subsequently began to decline slowly until returning to baseline at parturition (Fig. 4).

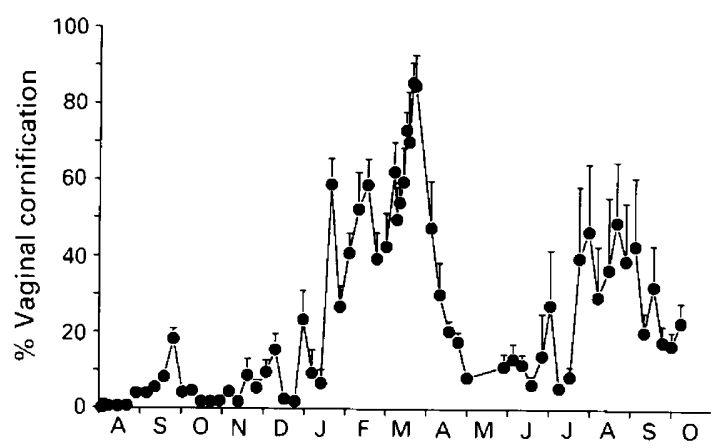

Fig. 2. Seasonal changes in percentage of cornified epithelial cells (mean \pm s.e.m.) in vaginal lavages of 6 captive steppe polecats maintained in a natural photoperiod. The second peak of vaginal cornification observed in August was due to 3 of 6 females returning to oestrus after removal of their 10-11-week-old kits. The mean values for vaginal cornification in the remaining 3 females was low $(2-17 \%)$.

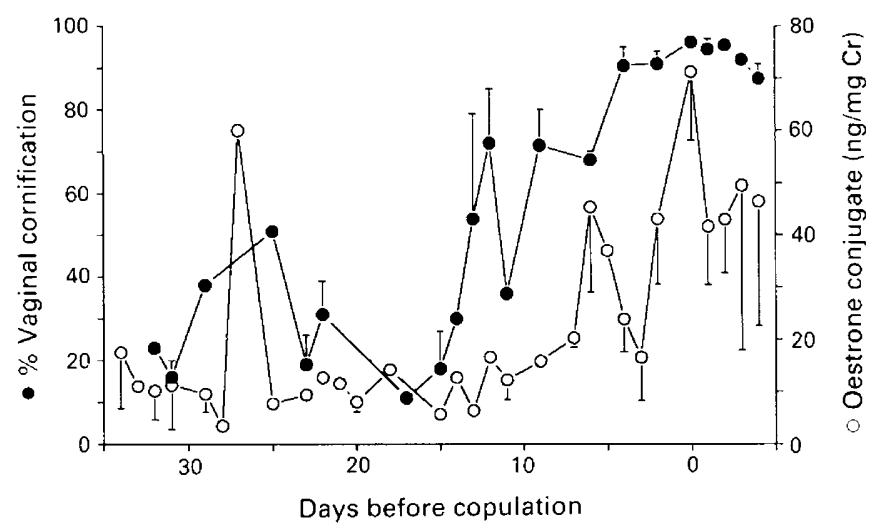

Fig. 3. Vaginal cornification and urinary oestrone conjugate concentrations from 35 days before copulation to 5 days after mating. Day 0 represents the day of copulation. Values are mean \pm s.e.m. for $1-5$ observations.

Urinary progesterone remained at baseline levels $0.27 \pm 0.02 \mathrm{ng} / \mathrm{mg} \mathrm{Cr}$ ) until 2 days post coitum, when progesterone concentrations began to rise (Fig. 4). Concentrations of progesterone reached a peak at 13 days post coitum and remained elevated above baseline until parturition. 

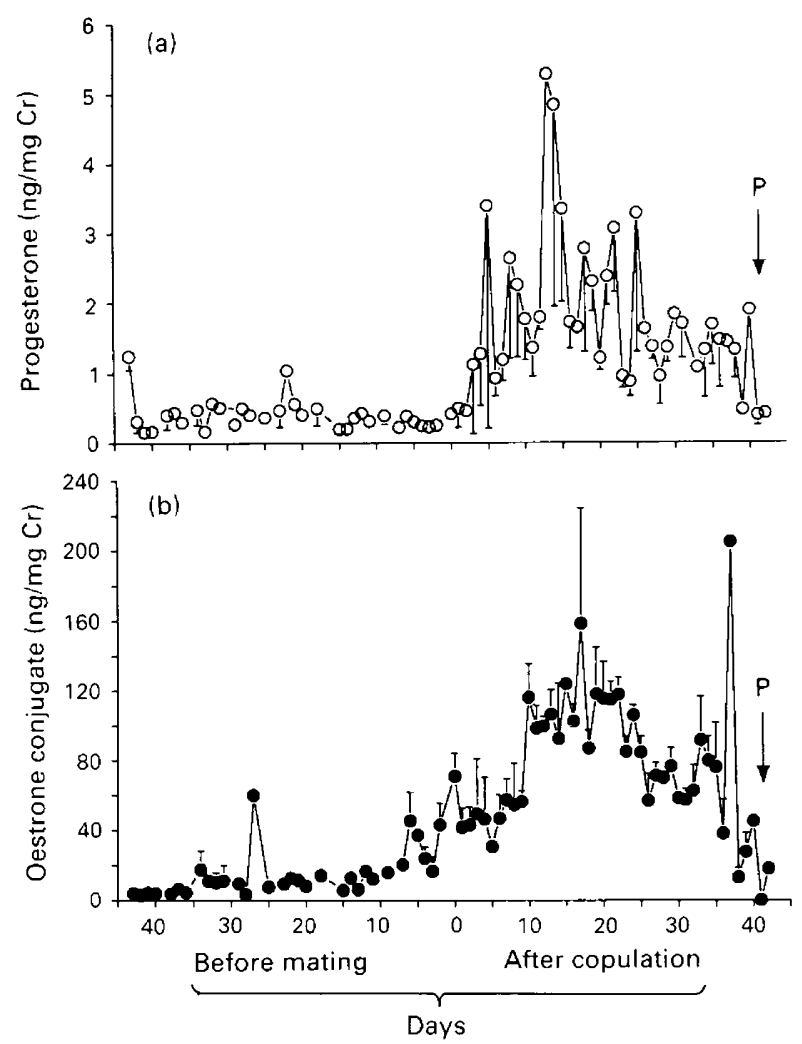

Fig. 4. Urinary progesterone concentrations (a) and urinary oestrone conjugate concentrations (b) from 43 days before copulation to parturition $(P)$. Values are mean \pm s.e.m. for 1-5 observations.

Most males attempted to mount receptive females within a few minutes after the female was introduced and generally achieved intromission within $15-35 \mathrm{~min}$. Some males were more tentative, perhaps due to their inexperience, and were considerably slower in achieving intromission. Copulation was quite prolonged in most cases, lasting 55-180 $\mathrm{min}$.

Polecats maintained in a natural photoperiod copulated between 30 March and 11 August, with all 6 females copulating for the first time by 8 April. After copulation vaginal cornification gradually decreased, then fell abruptly to $40 \%$ at Day 10 , and continued to decline with erratic fluctuations during the remainder of gestation. Vulval regression was complete in most pregnant females within 13 days after copulation. A laparotomy was performed on 1 female on Day 13 of pregnancy. Small uterine swellings (presumptive implantation sites) measuring $5.3 \times 6.5 \mathrm{~mm}$ in diameter were observed. A laparotomy was performed on another female on Day 14 of pregnancy. She had uterine swellings measuring $4.9 \times 5.0 \mathrm{~mm}$ in diameter. These females gave birth to kits 29 and 28 days later. Parturitions occurred between 9 May and 19 September, with females completing their first parturition by 19 May. Gestation averaged $40.8 \pm 1.2$ days and ranged from 39 to 43 days. Litter size in primiparous females averaged $6.8 \pm 1.9$ kits and ranged from 4 to 10 . The sex ratio of 49 surviving kits from 9 litters was 1 male: $1 \cdot 35$ females and was highly skewed within and between litters.

Of 12 females that had mated, 3 were apparently pseudopregnant as they exhibited vulval regression, vaginal cytology and mammary development similar to that observed in females that gave birth to live young. The only pseudopregnant animal in which urinary steroids were measured had oestrone conjugate and progesterone profiles equivalent to those of pregnant females. All 3 
females and an additional female whose litter died within 4 days after parturition returned to oestrus within 6-25 days after the expected date of parturition (Table 1). No attempt was made to remate any of the first 3 animals whereas the 4 th animal, whose litter died, was successfully remated and gave birth to 6 live kits.

Of 6 females maintained in a natural photoperiod, 3 returned to oestrus in early August after their 10-11-week-old kits had been removed (Table 1). One of these mated successfully, and subsequently produced a litter 39 days later. No attempt was made to mate the others.

Table 1. Data regarding return to oestrus in captive steppe polecats

\begin{tabular}{|c|c|c|c|}
\hline $\begin{array}{l}\text { Female } \\
\text { no. }\end{array}$ & $\begin{array}{l}\text { Return to } \\
\text { 2nd oestrus }\end{array}$ & $\begin{array}{l}\text { Date noticed return } \\
\text { to } 2 \text { nd oestrus }\end{array}$ & $\begin{array}{l}\text { Duration of } \\
\text { 2nd oestrus }\end{array}$ \\
\hline 26 & 6 days after kits died & 17 May 1988 & 2 days before remating \\
\hline 30 & $\begin{array}{l}7-8 \text { days after Day } 42 \text { of } \\
\text { pseudopregnancy }\end{array}$ & 20 May 1988 & 6 days \\
\hline $2^{*}$ & $\begin{array}{l}14 \text { days after Day } 42 \text { of } \\
\text { pseudopregnancy }\end{array}$ & 15 February 1988 & 3-9 days \\
\hline $10^{*}$ & $\begin{array}{l}\text { 23-25 days after Day } 42 \text { of } \\
\text { pseudopregnancy }\end{array}$ & 24 February 1988 & $\begin{array}{l}\text { Sporadic oestrus, } 3 \text { times remaining in } \\
\text { oestrus for about } 6 \text { days each time }\end{array}$ \\
\hline 32 & $\begin{array}{l}4-10 \text { days after removal of } 10 \text {-week- } \\
\text { old kits }\end{array}$ & 8 August 1988 & 5-9 days before remating \\
\hline 18 & $\begin{array}{l}4-10 \text { days after removal of } 10 \text {-week- } \\
\text { old kits }\end{array}$ & 8 August 1988 & $\begin{array}{l}\text { Exhibited oestrus twice, remaining } \\
\text { oestrous for about } 6-7 \text { days each time }\end{array}$ \\
\hline 20 & $\begin{array}{l}19 \text { days after removal of } 11 \text {-week-old } \\
\text { kits }\end{array}$ & 17 August 1988 & 24 days \\
\hline
\end{tabular}

*Females were exposed to short- and long-day experimental photoperiods. All others were maintained in a natural photoperiod.

The duration of oestrus (i.e. period during which the vulva remained enlarged and vaginal cornification exceeded $88 \%$ ) in 4 unmated females was about 30 days and did not appear to vary between pre- and post-partum oestrous periods. One female exhibited $>90 \%$ vaginal cornification for 24 consecutive days before becoming anoestrous. Another female exhibited this same pattern for 23 consecutive days before being mated. Three other females went through 3-4 periods lasting 5-9 days during which vaginal cornification exceeded $88 \%$. Each such period was interspersed by 1-4 days during which vaginal cornification ranged from 60 to $85 \%$ without any significant changes in vulval size. Thereafter the percentage of cornified cells in the vaginal lavages abruptly dropped to $<77 \%$ and slowly declined, as did vulval swelling.

\section{Kit development}

The testes of males that died shortly after birth were abdominal. Testicular descent was completed some time between the 8th and 16th day after birth. One 8-day-old kit had one scrotal and one abdominal testis, whereas both testes of the 16-day-old kit were scrotal. Kits weighed $\sim 8.4 \mathrm{~g}$ at birth and had increased to $23 \mathrm{~g}$ by the end of the 1 st week. Weights of male and female kits were essentially indistinguishable until the 9th week, when the weights of males began to increase more rapidly than in females. Kits reached adult weight about 4 months (110 days) after birth. Mature males were $\sim 14 \%$ longer from the tip of their nose to the tip of their tail and $\sim 36 \%$ heavier than mature females. The young kits began to open their eyes 31 days after birth and both eyes were wide open by Day 41. Kits consumed chopped liver as early as Day 25. Males maintained in a natural photoperiod were capable of mating at 10-11 months and females at 11 months. 


\section{Discussion}

Urinary oestrone conjugates and degree of vaginal cornification are good indicators of oestrus in the polecat. This finding is similar to Ryan's (1984) report of vulval oedema increasing in concert with serum oestradiol values. Vulval enlargement is also a useful indicator of oestrus in the polecat, although the vulva does not become quite as enlarged and the degree of oedema varies more between polecats than in the domestic ferret. The profile of urinary progesterone concentrations observed during pregnancy in the steppe polecat resembled that of serum progesterone during pregnancy in the domestic ferret (Heap \& Hammond, 1974), with levels peaking near the time of implantation, declining during the last third of pregnancy, and reaching baseline levels at parturition. Urinary progesterone and oestrone conjugate exhibit very similar patterns throughout pregnancy. The marked elevation of oestrogens during pregnancy has not previously been described for the domestic ferret (Heap \& Hammond, 1974) or in other mustelids (mink: Pilbeam et al., 1979; European badger: Mondain-Monval et al., 1980; spotted skunk: Ravindra \& Mead, 1984). Further studies to ascertain the source of these urinary oestrogens and comparison to serum concentrations in steppe polecats are necessary.

Male polecats exposed to natural photoperiods are probably first able to mate in late February and remain fertile through July and perhaps into August. Breeding in the laboratory and field commences in late March and continues through April (Zheng et al., 1983). Although our data indicate that some captive steppe polecats are polyoestrous in captivity, we believe this species only produces a single litter each year in the wild, as indicated by field studies in China (Zheng et al., 1983). Under laboratory conditions, pseudopregnant females or those that lose their litters within a few days after parturition can return to oestrus (Tumanov, 1977). This has also been observed in other captive mustelids such as the European mink (Mustela lutreola) (Moshonkin, 1981), mountain weasel $(M$. altica) (Tumanov, 1977), and striped skunk ( $M$. mephitis) (Wade-Smith \& Richmond, 1978). Moreover, Lui \& Yang (1981, as cited by Zheng et al., 1983) reported that 50\% of their captive steppe polecats produced second litters, which is similar to our observations that $50 \%$ of the polecats exposed to a natural photoperiod came into oestrus after removal of their 10 -week-old kits. The discrepancy between single litters in the field and multiple litters in captivity may be due to enhanced nutrition and a less rigorous life style in captivity.

The reproductive cycle of the steppe polecat bears many striking similarities to and a few slight differences from 2 other closely related species, the black-footed ferret (Mustela nigripes) and the domesticated European ferret ( $M$. putorius furo). All 3 species appear to have gestation periods lasting from 39 to 45 days and may in fact not differ from one another. However, Schmidt (1932) reported gestation in steppe polecats as being 36-37 days. The differences between our data and his are too great to be reconciled by differences in the manner in which the first and last day of gestation were determined. The vulva of $M$. putorius becomes quite enlarged at oestrus, whereas that of $M$. eversmanni and $M$. nigripes exhibits lesser degrees of swelling (Hillman \& Carpenter, 1983). M. eversmanni and $M$. putorius reportedly interbreed in the wild and are known to do so in captivity (Ternovskaya \& Ternovskii, 1977). Onset of the breeding season of all 3 ferrets is remarkably similar and usually begins in March. However, domestic ferrets can remain in constant oestrus for up to 6 months if not mated (Marshall, 1904), whereas our polecats appeared to exhibit oestrus sporadically and never remained in oestrus for more than 30 days. Less information has been published regarding the oestrous cycle of the black-footed ferret; however, it reportedly is monoestrous (Hillman \& Carpenter, 1983) and only produces a single litter each year. Litter size is generally greater in both the domestic ferret and steppe polecat than in the black-footed ferret, whose largest recorded litter is 6 (Anonymous, 1987).

We thank Dr Tom Thorne of the Wyoming Game and Fish Department for the gift of the 20 polecats. This study was supported by a grant from the U.S. Fish and Wildlife Service. The Idaho Cooperative Fish and Wildlife Research Unit is funded and supported by Idaho Fish and Game, 
University of Idaho, U.S. Fish and Wildlife Service, and the Wildlife Management Institute. This is contribution No. 480 from the University of Idaho, Forestry and Wildlife Resources Experiment Station.

\section{References}

Abraham, G.E., Swerdloff, R., Tulchinsky, D. \& Odell, W.D. (1971) Radioimmunoassay of plasma progesterone. J. clin. Endocr. Metab. 32, 619-625.

Anonymous (1987) BFF babies are born. The Blackfooted Ferret Newsletter 4, 1 (Wyoming Game \& Fish, Laramie.)

Carpenter, J.W. \& Hillman, C.N. (1978) Husbandry, reproduction, and veterinary care of captive ferrets. A. Proc. Am. Assoc. Zoo Vet. 3647.

Czekala, N.M., Roser, J.F., Mortensen, R.B., Reichard, T. \& Lasley, B.L. (1988) Urinary hormone analysis as a diagnostic tool to evaluate the ovarian function of female gorillas (Gorilla gorilla). J. Reprod. Fert. 82, $255-261$.

Hammond, J. \& Walton, A. (1934) Notes on ovulation and fertilization in the ferret. $J$. exp. Biol. 11, 307-319.

Healey, P. \& Sadleir, R.M.F.S. (1966) The construction of rectal electrodes for electro-ejaculation. $J$. Reprod. Fert. 11, 299-301.

Heap, R.B. \& Hammond, J., Jr (1974) Plasma progesterone levels in pregnant and pseudopregnant ferrets. $J$. Reprod. Fert. 39, 149-152.

Hillman, C.N. \& Carpenter, J.W. (1983) Breeding biology and behaviour of captive black-footed ferrets (Mustela nigripes). Int. Zoo Yb. 23, 186-191.

Lui, L.Y. \& Yang, G.F. (1981) Raising and reproduction of masked polecat. Fur Animal Raising 2, 45-48.

Marshall, F.H.A. (1904) The oestrous cycle in the common ferret. Quart. J. Microsc. Sci. 48, 323-345.

Mondain-Monval, M., Bonnin, M., Canivenc, R. \& Scholler, R. (1980) Plasma estrogen levels during delayed implantation in the European badger (Meles meles L.). Gen. comp. Endocrinol. 41, 143-149.

Moshonkin, N.N. (1981) Potential polyestricity of the mink (Lutreola lutreola). Zool. Zh. 60, 1731-1734.

Novikov, G.A. (1956) Carnivorous mammals of the fauna of the USSR. Zool. Instit. Acad. Sci. USSR, No. 62. (Israeli Program for Scientific Translations, 1962, 62, 1-284.)

O'Brien, S.J., Martenson, J.S., Eichelberger, M.A., Thorne, E.T. \& Wright, F. (1989) Biochemical genetic variation and molecular systematics of the blackfooted ferret, Mustela nigripes. In Conservation Biology and the Black-footed Ferret, pp. 21-31. Eds U. S. Seal, E. T. Thorne, M. Bogen \& S. H. Anderson. Yale University Press, New Haven.
Pilbeam, T.E., Concannon, P.W. \& Travis, H.F. (1979) The annual reproductive cycle of mink (Mustela vison). J. Anim. Sci. 48, 578-584.

Ravindra, R. \& Mead, R.A. (1984) Plasma estrogen levels during pregnancy in the western spotted skunk. Biol. Reprod. 30, 1153-1159.

Robinson, A. (1918) The formation, rupture and closure of ovarian follicles in ferrets and ferret-polecat hy. brids and some associated phenomena. Trans. Roy. Soc. Edinb. 52, 303-362.

Ryan, K.D. (1984) Hormonal correlates of photoperiodinduced puberty in a reflex ovulator, the female ferret (Mustela furo). Biol. Reprod. 31, 925-935.

Schmidt, F. (1932) Der Steppeniltis (Putorius eversmanni Less). Deutsche Pelztierzuchter 7, 453-458.

Shideler, S.E., Czekala, N.M., Kasman, L.H., Lindburg, D.G. \& Lasley, B.L. (1983) Monitoring ovulation and implantation in the lion-tailed macaque (Macaca silenus) through urinary estrone conjugate evaluations. Biol. Reprod. 29, 905-911.

Stroganov, S.U. (1962) Carnivorous Mammals of Siberia, pp. 35!-359. Israeli for Program Scientific Translations, 1969, Jerusalem.

Taussky, H.H. \& Kurzmann, G. (1954) A microcolorimetric determination of creatinine in urine by the Jaffe reaction. J. biol. Chem. 208, 853-861.

Ternovskaya, Yu.G. \& Ternovskii, D.V. (1977) Prospects of using polecats for artificial breeding. In Biology and Pathology of Farm-bred Fur-bearing Animals, pp. 163-164. Ed. V. G. Safonov. [In Russian: translation published 1985 by Amerind Publishing Co. Pvt. Ltd, New Delhi.]

Tumanov, I.L. (1977) O potentsial'noi poliestrichnosti nekotorykh vidov Kun'ikh (Mustelidae). Zool. $Z h$. 56, 619-625.

Wade-Smith, J. \& Richmond, M.E. (1978) Reproduction in captive striped skunks (Mephitis mephitis). Am. Midl. Nat. 100, 452-455.

Zheng, S., Zeng, J. \& Cui, R. (1983) On ecology and energy dynamics of masked polecat (Mustela eversmanni) in Haibei, Qinghai Province. Acta theriol sin. $3,35-46$. 